\title{
In Vitro Synthesis of a Larger Precursor of Tobacco $\beta-1,3-$ Glucanase
}

\author{
Hideaki SHINSHI* and Kunio KATō \\ Central Research Institute, Japan Tobacco and Salt Public Corporation, \\ 6-2 Umegaoka, Midori-ku, Kanagawa 227, Japan
}

Received September 28, 1982

\begin{abstract}
Translation of total RNA prepared from cultured tobacco cells by the guanidine- $\mathrm{HCl}$ method in a cell-free reticulocyte lysate system results in the synthesis of a larger precursor of $\beta-1,3-$ glucanase (EC 3.2.1.39). This identification was based on immunoprecipitation with specific anti- $\beta$ 1,3-glucanase antibody. Furthermore, sodium dodecyl sulfate polyacrylamide gel electrophoresis after limited proteolysis and two dimensional tryptic fingerprintings of $\beta$-1,3-glucanase and its precursor show a high degree of similarity. The precursor is larger than the mature protein by 4,000 daltons. $\beta$-1,3-Glucanase mRNA was partially purified by oligo(dT)-cellulose column chromatography and sucrose density gradient centrifugation. The sedimentation coefficient of the mRNA was estimated to be about $17 \mathrm{~S}$.
\end{abstract}

Some enzymes such as $\beta$-1,3-glucanase, peroxidase and phosphodiesterase are present at much higher levels in suspension cultured tobacco cells than in differentiated tissues of the plant. ${ }^{1 \sim 3)}$ Their mRNAs are considered to be enriched in the culture cells, but it is not clear which specific regulatory mechanism accounts for this phenomenon. To understand the biosynthetic regulation of plant enzymes, we chose $\beta$-1,3-glucanase as a model system.

$\beta-1,3-$ Glucanase has been purified to homogeneity, and the enzyme comprises one of the major soluble proteins of cultured tobacco cells. ${ }^{4)}$ The synthesis of this protein has been suggested to be under hormonal and developmental control. ${ }^{5,6)}$ Any study of the regulatory mechanisms in plant gene expression would be facilitated by the identification and purification of a specific mRNA. This paper describes the characterization of a specific antibody directed against the purified $\beta$-1,3glucanase, and the in vitro synthesis of a larger precursor of this enzyme.

\section{MATERIALS AND METHODS}

Growth of tobacco cells. Cells of tobacco (Nicotiana tabacum, cultivar Bright Yellow) were cultured in suspension as has been previously described. ${ }^{1)}$ After 4 days, the cells were harvested on a porous glass filter and stored at $-70^{\circ} \mathrm{C}$ until enzyme extraction. Proteins were labeled in vivo with $\left[{ }^{14} \mathrm{C}\right]$ leucine (New England Nuclear, $0.5 \mu \mathrm{Ci} / \mathrm{ml}$ ) for $10 \mathrm{hr}$ at $28^{\circ} \mathrm{C}$ in the culture medium.

Preparation of tobacco $\beta$-1,3-glucanase. $\beta$-1,3-Glucanase was purified from the cultured tobacco cells as already described. ${ }^{4)}$ The purified glucanase migrated as a single protein band in polyacrylamide gel electrophoresis with or without sodium dodecyl sulfate (SDS).

Preparation of antibody. To prepare anti- $\beta-1,3-$ glucanase antibody, $8 \mathrm{mg}$ of purified glucanase emulsified with Freund's complete adjuvant was injected intramuscularly into the hind legs of medium weight rabbit. After one week a second injection of half quantities of antigen and adjuvant was given, and four weeks after the last injection, blood was collected by cardiac puncture. The IgG was partially purified by precipitation with ammonium sulfate and passing through a DEAE-cellulose column equilibrated with $10 \mathrm{~mm}$ sodium phosphate buffer ( $\mathrm{pH}$ 7.2). The specificity of the antibody directed against tobacco $\beta$-1,3-glucanase was tested by Ouchterlony double immunodiffusion $^{7)}$ and immunoelectrophoresis ${ }^{8)}$ using $1 \%$ agarose in $0.05 \mathrm{~m}$ sodium barbital buffer ( $\mathrm{pH}$ 8.6). Proteins were stained with Coomassie brilliant blue.

Preparation of RNA. Total cellular RNA from the tobacco cultured cells or leaves was extracted by the guanidine- $\mathrm{HCl}$ technique with modifications.9,10) Frozen 
cells $(140 \mathrm{~g})$ stored at $-70^{\circ} \mathrm{C}$ were broken into pieces and homogenized at room temperature in a juicer in $200 \mathrm{ml}$ of $10 \mathrm{~mm}$ Tris- $\mathrm{HCl}$ buffer ( $\mathrm{pH} 8.0$ ) containing $8 \mathrm{M}$ guanidine$\mathrm{HCl}$ and $0.1 \mathrm{M}$ 2-mercaptoethanol. The homogenate was centrifuged at $5,000 \times g$ for $15 \mathrm{~min}$ to remove cell debris and the supernatant solution was again centrifuged at $20,000 \times g$ for $20 \mathrm{~min}$. To the supernatant 0.02 volume of $5 \mathrm{M}$ sodium acetate buffer $(\mathrm{pH} 5.0)$ and 2 volumes of ethanol were added with stirring. This solution was allowed to stand at $-20^{\circ} \mathrm{C}$ overnight to precipitate the nucleic acid. The material was sedimented by centrifugation for $15 \mathrm{~min}$ at $0^{\circ} \mathrm{C}$ and $5,000 \times g$, and the pellet was dispersed in ethanol and centrifuged for $10 \mathrm{~min}$ at $5,000 \times g$. The pellet was suspended in $20 \mathrm{~mm}$ Tris- $\mathrm{HCl}$ buffer ( $\mathrm{pH} 8.5$ ) containing $0.1 \mathrm{M} \mathrm{NaCl}, 2 \mathrm{~mm}$ EDTA and $0.5 \%$ lauryl sarcosine with the aid of a Dounce homogenizer, and extracted twice with an equal volume of watersaturated phenol and chloroform $(1: 1, \mathrm{v} / \mathrm{v})$. The aqueous phase was centrifuged to remove insoluble materials, and the RNA was recovered by ethanol precipitation. Low molecular weight RNA, DNA and carbohydrate were removed by washing the precipitate twice with $2 \mathrm{M} \mathrm{LiCl}$ and once with $3 \mathrm{~m}$ sodium acetate ( $\mathrm{pH}$ 6.0). The pellet was dissolved in water and centrifuged to remove insoluble materials and the RNA was precipitated by ethanol. RNA concentration was determined spectrophotometrically on the assumption that a $1 \mathrm{mg} / \mathrm{ml}$ solution had an absorbance of 20 at $260 \mathrm{~nm}$. Poly(A)-containing RNA was obtained from total RNA by two cycles of an oligo(dT)-cellulose column (Collaborative Research, Inc., type 2). ${ }^{11)}$ Typically, the poly(A)-containing RNA fraction represented $0.5 \%$ of the total RNA applied to the column.

Translation of RNA in a cell-free translation system. RNA was translated in a commercially available mRNA dependent cell-free reticulocyte lysate translation system in the presence of $\left[{ }^{35} \mathrm{~S}\right]$ methionine (Amersham or New England Nuclear). Incubation was performed at $30^{\circ} \mathrm{C}$ for $90 \mathrm{~min}$. The maximal incorporation of radioactivity into the polypeptides was obtained at $80 \mathrm{mM} \mathrm{K}^{+}$and $1.3 \mathrm{~mm}$ $\mathrm{Mg}^{++}$of the reaction mixture. Incorporation as a function of RNA concentration reached a maximum at $6 \mu \mathrm{g}$ per reaction mixture. Usually $5 \mu \mathrm{g}$ of total RNA or $0.1 \mu \mathrm{g}$ of poly(A)-containing RNA per $25 \mu \mathrm{l}$ assay were used.

Sucrose density gradient centrifugation. Sucrose density gradient centrifugation was performed using a Hitachi RPS-40 rotor for $20 \mathrm{hr}$ at $29,000 \mathrm{rpm}$ and $4^{\circ} \mathrm{C}$. Approximately $100 \mu \mathrm{g}$ of poly(A)-containing RNA was dissolved in $10 \mathrm{~mm}$ Tris- $\mathrm{HCl}$ buffer $(\mathrm{pH} \mathrm{7.5)}$ and $1 \mathrm{~mm}$ EDTA, heated to $65^{\circ} \mathrm{C}$ for $5 \mathrm{~min}$, quickly cooled on ice, and then immediately layered on a linear 5 to $25 \%(\mathrm{w} / \mathrm{v})$ sucrose density gradient in $50 \mathrm{~mm}$ Tris- $\mathrm{HCl}(\mathrm{pH} \mathrm{7.5),1} \mathrm{mM}$ EDTA and $1 \%$ lauryl sarcosine. Fractions were collected and the RNA in each fraction was precipitated with ethanol. E. coli, ribosomal RNA and tRNA were sedi- mented in a parallel tube as size markers.

Immunoprecipitation. Phenylmethylsulfonyl fluoride was added at the end of the translation period in a concentration of $1 \mathrm{mM}$, and the translation mixtures were centrifuged at $15,000 \times g$ for $5 \mathrm{~min}$. For immunoprecipitation, polypeptides in the supernatant were immunoprecipitated in a $300 \mu \mathrm{l}$ reaction mixture containing $1 \%$ Triton $\mathrm{X}-100,1 \%$ sodium deoxycholate, $10 \mathrm{~mm}$ Tris- $\mathrm{HCl}\left(\mathrm{pH}^{\prime}\right.$ $8.0), 0.15 \mathrm{M} \mathrm{NaCl}, 10 \mu \mathrm{g}$ of unlabeled $\beta$-1,3-glucanase and $100 \mu \mathrm{g}$ of antibody. The mixture was incubated at $37^{\circ} \mathrm{C}$ for $1 \mathrm{hr}$ and then further incubated at $4^{\circ} \mathrm{C}$ overnight. The immunoprecipitate was sedimented through a $100 \mu \mathrm{l}$ sucrose cushion of $1 \mathrm{M}$ sucrose containing the above detergents and buffer. The precipitate was washed 3 times in the detergents and buffer, and twice with $10 \mathrm{~mm}$ sodium phosphate buffer ( $\mathrm{pH}$ 7.2).

SDS polyacrylamide gel electrophoresis. SDS polyacrylamide gel electrophoresis was accomplished on slab gels in a discontinuous buffer system as described by Laemmli. ${ }^{12)}$ The protein samples were boiled for $5 \mathrm{~min}$ in the SDS sample buffer containing $2 \% \mathrm{SDS}$, $0.065 \mathrm{M}$ Tris- $\mathrm{HCl}(\mathrm{pH} 6.8), 10 \%$ glycerol and $5 \% 2$ mercaptoethanol before analysis. After electrophoresis, the gels were fixed in $7.5 \%$ acetic acid and $25 \%$ isopropyl alcohol, and either dried directly for autoradiography or prepared first for fluorography with $\mathrm{EN}^{3} \mathrm{HANCER}$ (New England Nuclear) and exposed on Kodak X-Omat R X-ray films at $-70^{\circ} \mathrm{C}$.

Limited proteolysis on SDS polyacrylamide gel. Peptide mapping of the in vivo and in vitro synthesized $\beta$-1,3glucanase by limited proteolysis on SDS polyacrylamide gel was performed according to the procedure of Cleveland et al. ${ }^{13)}$ Cell-free translation products and in vivo synthesized proteins were immunoprecipitated by anti-glucanase antibody and the solubilized immunoprecipitates were fractionated by SDS polyacrylamide gel electrophoresis. The protein bands located on dried gels by their autoradiographic patterns were excised, and then rehydrated for $30 \mathrm{~min}$ in equilibration buffer $(0.065 \mathrm{M}$ Tris$\mathrm{HCl}, \mathrm{pH} 6.8,0.1 \%$ SDS, $1 \mathrm{~mm}$ EDTA). Each slice was next put into a separate slot of SDS polyacrylamide slab gel containing a $14 \%$ running gel. The gel slices were overlaid with Staphylococcus aureus V8 protease (Miles Laboratories, Inc.) in the buffer containing 5\% glycerol. The samples were then overlaid with running buffer and electrophoresis was performed.

Two dimensional tryptic fingerprints. An SDS polyacrylamide gel containing the immunoprecipitate of in vitro synthesized $\left[{ }^{35} \mathrm{~S}\right]$ methionine labeled $\beta$-1,3-glucanase was autoradiographed. The $\beta$-1,3-glucanase precursor band was excised and the gel slice was extracted for 1 day with $25 \%$ isopropyl alcohol and $10 \%$ acetic acid, then for 3 days with $25 \%$ isopropyl alcohol and for $12 \mathrm{hr}$ with $10 \%$ 
methanol, and finally lyophilized. ${ }^{14)}$ This was digested for 1 day at $37^{\circ} \mathrm{C}$ with $25 \mu \mathrm{g}$ of L-1-tosylamido-2-phenylethyl chloromethyl ketone-treated trypsin (Worthington) and $5 \mu \mathrm{g}$ of unlabeled glucanase in $0.1 \mathrm{M} \mathrm{NH}_{4} \mathrm{CO}_{3}$ buffer $(\mathrm{pH}$ 8.6). The supernatant was removed and the slice was soaked in water for $4 \mathrm{hr}$ at $37^{\circ} \mathrm{C}$. The supernatant was combined, lyophilized twice, dissolved in water and centrifuged to remove insoluble materials, then spotted on a cellulose plate and separated by two-dimensional thin layer chromatography. ${ }^{15)}$ Chromatography in the first dimension was carried out in pyridine-isoamyl alcoholwater, $7: 7: 6$, and in the second dimension in butanolpyridine-acetic acid-water, $5: 4: 1: 4$, containing $7 \% 2,5$ diphenyloxazole $\left.(\mathrm{w} / \mathrm{v}) .^{16}\right)$ Purified unlabeled $\beta$-1,3glucanase was separately digested with the trypsin and the peptides were separated as above. In the case of in vitro synthesized $\beta$-1,3-glucanase, the radiolabeled peptides were detected by exposing the dried chromatogram on $\mathrm{X}$ ray film at $-70^{\circ} \mathrm{C}$, whereas the tryptic peptides of native $\beta$-1,3-glucanase were stained with ninhydrin.

\section{RESULTS}

\section{Characterization of tobacco $\beta$-1,3-glucanase antibody}

In order to detect the synthesis of $\beta$-1,3glucanase in vitro, the preparation of a monospecific antibody was necessary. Figures 1a and $b$ represent the Ouchterlony double immunodiffusion and immunoelectrophoresis studies of the IgG obtained from rabbits immunized with purified $\beta$-1,3-glucanase. In both procedures, a single precipitin band appeared with either crude extract or with purified $\beta$ 1,3-glucanase. No bands appeared when an IgG obtained from preimmune rabbit was used. As further evidence for the specificity of the antibody, $\left[{ }^{14} \mathrm{C}\right]$ leucine labeled proteins extracted from cultured tobacco cells were immunoprecipitated with the antibody. As shown in Fig. 2 (lane 1), the immunoprecipitate shows one radioactive protein band, and this material co-migrated with standard $\beta$-1,3-glucanase. The antibody thus appeared to be specific for the enzyme and could be used for the characterization of its mRNA.

\section{Identification of $\beta$-1,3-glucanase synthesized in vitro}

Total cellular RNA from tobacco cultured

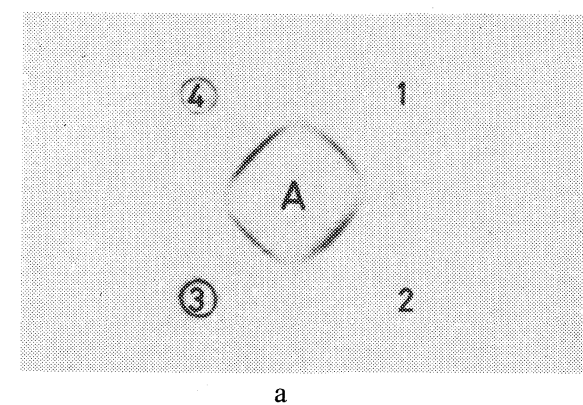

FIG. 1a. Double Immunodiffusion Tests of Tobacco $\beta$ 1,3-Glucanase and Anti- $\beta$-1,3-glucanase Antibody.

A, anti- $\beta$-1,3-glucanase IgG at a concentration of $6 \mathrm{mg} / \mathrm{ml}$ (center); 1 and 2 , pure $\beta$-1,3-glucanase at concentrations of 0.08 and $0.15 \mathrm{mg} / \mathrm{ml}$ respectively; 3 and 4 , crude extract at concentrations of 0.9 and $1.8 \mathrm{mg} / \mathrm{ml}$ respectively.

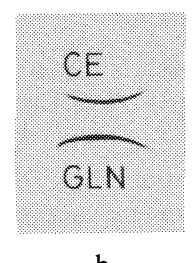

b

FIG. 1b. Immunoelectrophoresis of Anti- $\beta-1,3-$ glucanase Antibody.

$\mathrm{CE}$, crude extract at a concentration of $0.8 \mathrm{mg} / \mathrm{ml}$; GLN, pure $\beta$-1,3-glucanase at a concentration of $1.8 \mathrm{mg} / \mathrm{ml}$; center, anti- $\beta$-1,3-glucanase $\operatorname{IgG}$ at a concentration of $6 \mathrm{mg}$ protein $/ \mathrm{ml}$. Electrophoresis was from left to right.

cells was translated in the reticulocyte lysate system in the presence of $\left[{ }^{35} \mathrm{~S}\right]$ methionine, and the products were analyzed by SDS polyacrylamide gel electrophoresis (Fig. 2). As shown, we found that one product, with a molecular weight of 37,000 , had reacted with the anti- $\beta$ 1,3-glucanase antibody. This band was tentatively identified as the primary translation product of $\beta$-1,3-glucanase and hence would be a precursor to the enzyme that is 4,000 daltons larger than the mature form (Fig. 3). This band was prominent in the polypeptides translated from the mRNA of cultured tobacco cells, but the band was very faint in those translated from leaf mRNA. When the control IgG prepared from preimmune rabbit was substituted for the antibody, no specific immunoprecipitation bands were observed on gel analysis. 


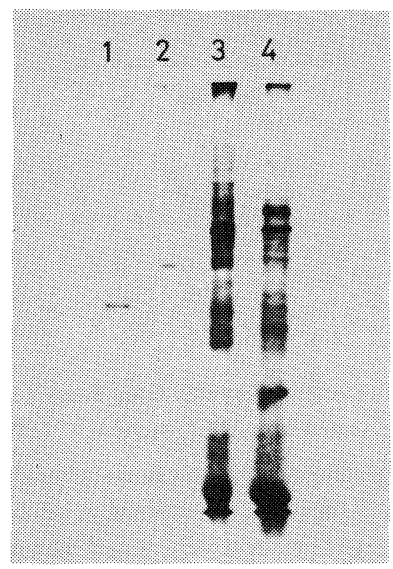

FIG. 2. Electrophoretic Analysis of Immunoprecipitate from In Vitro Synthesized Products with Anti- $\beta$-1,3glucanase Antibody.

Polypeptides were synthesized in a reticulocyte lysate system in the presence of $\left[{ }^{35} \mathrm{~S}\right]$ methionine and the products and immunoprecipitate were resolved by SDS polyacrylamide gel electrophoresis and visualized by fluorography. 1, immunoprecipitate with the antibody from a crude extract of cultured tobacco cells labelled in vivo with $\left[{ }^{14} \mathrm{C}\right]$ leucine; 2 , immunoprecipitate with the antibody from in vitro translated products directed by total RNA from cultured tobacco cells; 3, products translated from total RNA of cultured cells; 4, products translated from total leaf RNA.

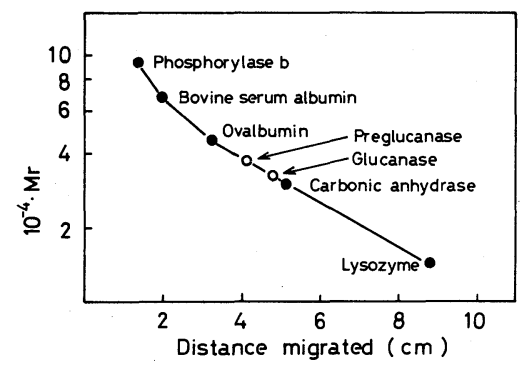

FIG. 3. Estimation of Molecular Weight of In Vitro Synthesized $\beta-1,3-$ Glucanase by $10 \%$ SDS Polyacrylamide Gel Electrophoresis.

The reference proteins are: phosphorylase $b$ ( $\mathrm{Mr} .92,500)$, bovine serum albumin $(69,000)$, ovalbumin $(46,000)$, carbonic anhydrase $(30,000)$ and lysozyme $(14,000)$.

\section{Limited Proteolysis}

To establish that the 37,000 dalton putative $\beta$-1,3-glucanase precursor contained the amino acid sequence of authentic $\beta$-1,3-glucanase, a limited proteolysis pattern and the tryptic fingerprints of these molecules were compared.

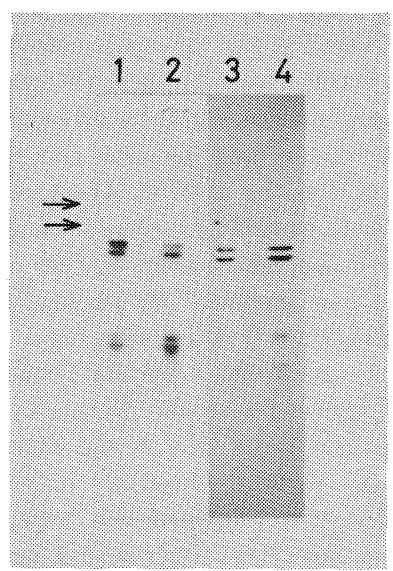

FIG. 4. Limited S. aureus V8 Protease Digestion Pattern of In Vivo and In Vitro Synthesized $\beta$-1,3-Glucanase.

Fractionation of in vivo and in vitro synthesized protein in SDS polyacrylamide gels and protease digestion of the protein bands were performed as described in the text. The protease digestion products were resolved in $14 \%$ SDS polyacrylamide gel electrophoresis and visualized by fluorography. 1 and 2, $\beta$-1,3-glucanase synthesized in vivo; 3 and $4, \beta$-1,3-glucanase synthesized in vitro; 1 and $3,1 \mu \mathrm{g}$ of $S$. aureus V8 protease added; 2 and $4,5 \mu \mathrm{g}$ of $S$. aureus V8 protease added. Upper and lower arrows indicate the position of uncleaved $\beta$-1,3-glucanase synthesized in vitro and in vivo, respectively.

Peptide maps of the in vitro and in vivo synthesized $\beta$-1,3-glucanase by limited Staphylococcus aureus V8 protease digestion on SDS polyacrylamide gel are shown in Fig. 4. Similar banding patterns were generated for the translation product and standard $\beta$-1,3glucanase. Four bands were observed by partial digestion of the in vivo and in vitro synthesized $\beta$-1,3-glucanase. When the protease concentration was increased, the two slow moving bands disappeared and two fast moving bands progesssively appeared.

\section{Tryptic fingerprint}

Two-dimensional fingerprints of the in vivo and in vitro synthesized $\beta$-1,3-glucanase are shown in Fig. 5. The major digestion products of the $\left[{ }^{35} \mathrm{~S}\right]$ methionine labeled $\beta$-1,3-glucanase synthesized in vitro precisely co-migrated with those of standard $\beta$-1,3-glucanase detected with ninhydrin. Two spots were observed in the $\beta$-1,3-glucanase precursor digestion prod- 

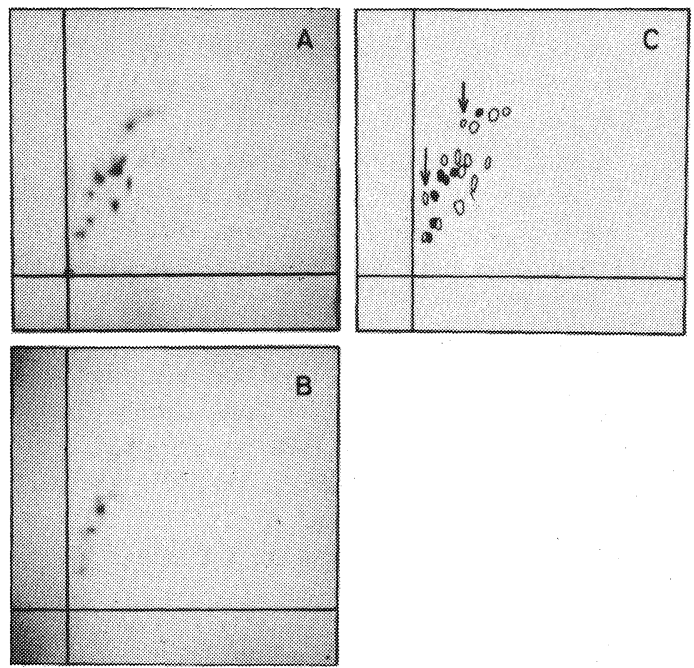

FIG. 5. Tryptic Fingerprint Analyses of In Vivo and In Vitro Synthesized $\beta$-1,3-Glucanase.

$\mathrm{A}$, in vivo synthesized $\beta$-1,3-glucanase. The tryptic peptides were detected by ninhydrin: $\mathrm{B}$, in vitro synthesized $\beta$-1,3glucanase. The tryptic peptides were detected by fluorography: $\mathrm{C}$, drawing. The filled circles represent spots found in $\beta$-1,3-glucanase synthesized in vivo and in vitro. Arrows indicate spots found only in vitro synthesized $\beta$-1,3glucanase.

ucts which had no apparent corresponding spots in the digestion products of the $\beta-1,3-$ glucanase standard.

These data strongly suggest that the 37,000 dalton precursor does contain the $\beta-1,3-$ glucanase amino acid sequence.

Analysis of $\beta$-1,3-glucanase $m R N A$ by sucrose density gradient centrifugation

In order to gain some preliminary information as to the size of the $\beta$-1,3-glucanase mRNA molecule, the distribution of glucanase mRNA activity on a sucrose density gradient was investigated. Poly(A)-containing RNA was fractionated by sucrose density gradient centrifugation and the different collected fractions in an equal volume were assayed in the reticulocyte lysate system for their $\beta$-1,3glucanase mRNA activity by immunoprecipitation with the antibody. As shown in Fig. 6, the peak of $\beta$-1,3-glucanase mRNA activity was found in fraction 12 , and the sedimentation coefficient of this RNA was estimated to

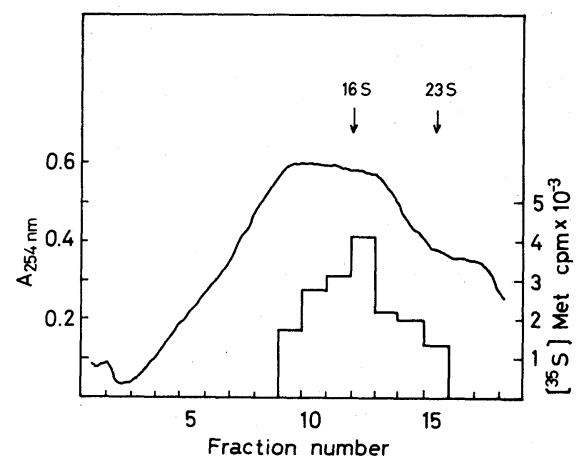

FIG. 6. Sucrose Density Gradient Centrifugation of $\beta$ 1,3-Glucanase mRNA.

About $100 \mu \mathrm{g}$ of poly(A)-containing RNA was fractionated by 5 to $25 \%(\mathrm{w} / \mathrm{v})$ sucrose density gradient centrifugation. The content was collected through a flow cell and the absorbance at $254 \mathrm{~nm}$ was recorded. RNA in each of the fractions (Fr. 9 15) was precipitated with ethanol and dissolved in water for use in the in vitro translation assay. The histogram represents the fractions collected and assayed for $\beta$-1,3-glucanase synthesis by immunoprecipitation with anti- $\beta$-1,3-glucanase antibody.

be $17 \mathrm{~S}$.

\section{DISCUSSION}

The results presented here demonstrate that the primary translation product of $\beta-1,3-$ glucanase mRNA is approximately 37,000 daltons, which is about 4,000 daltons larger than the mature $\beta$-1,3-glucanase. On the basis of immunological properties, and similarities of the limited proteolysis pattern and twodimensional tryptic fingerprints between the in vivo and in vitro synthesized $\beta$-1,3-glucanase, we have concluded that the protein is synthesized in vitro as a precursor form. Consequently, processing of nascent polypeptide may be involved during the in vivo synthesis of $\beta$-1,3-glucanase.

It remains unresolved whether the 37,000 dalton precursor has $\mathrm{NH}_{2}$-terminal or $\mathrm{COOH}$ terminal extensions. It has been shown that proteins segregated into membranes are synthesized with an $\mathrm{NH}_{2}$-terminal extension of 15 to 30 amino acids and processed to mature forms by co-translation or post-translation. ${ }^{17,18)}$ Larger precursor molecules of the 
polypeptides destined for integration into plant cell organelles have been described. These include storage proteins sequestered within protein bodies, glyoxysomal enzymes and chloroplast proteins. ${ }^{19 \sim 27)}$ The cellular localization and intracellular site for synthesis of tobacco $\beta$-1,3-glucanase remain to be established.

The data presented in this paper are an important prelude to recombinant DNA studies of the $\beta$-1,3-glucanase gene. The cDNA clones for the $\beta$-1,3-glucanase mRNA will provide a probe to isolate its gene, and to analyze RNA transcripts of the gene.

\section{REFERENCES}

1) K. Katō, A. Yamada and M. Noguchi, Agric. Biol. Chem., 37, 1269 (1973).

2) H. Shinshi and M. Noguchi, Phytochemistry, 15, 556 (1976).

3) H. Shinshi and K. Katō, Phytochemistry, 16, 1661 (1977).

4) H. Shinshi and K. Katō, Agric. Biol. Chem., 47, 1455 (1983).

5) A. E. Moore and B. A. Stone, Planta, 104, 93 (1972).

6) F. B. Abeles and L. E. Forrence, Plant Physiol., 45, 395 (1970).

7) O. Ouchterlony, "Progress in Allergy," Vol. 5, ed. by P. Kallos, Karger, Basel, 1958, pp. 1 78 .

8) P. Garbar and C. A. Williams, Biochim. Biophys. Acta, 10, 193 (1953).

9) R. A. Cox, "Methods in Enzymology," Vol. 12B, ed. by L. Grossman and K. Moldave, Academic Press, New York, 1968, pp. 120 129.
10) J. M. Chirgwin, A. E. Przybyla, R. J. MacDonald and W. J. Rutter, Biochemistry, 18, 5294 (1979).

11) H. Aviv and P. Leder, Proc. Natl. Acad. Sci. U.S.A., 69, 1408 (1972).

12) U. K. Laemmli, Nature, 227, 680 (1970).

13) D. W. Cleveland, S. G. Fischer, M. W. Kirschner and U. K. Laemmli, J. Biol. Chem., 252, 1102 (1977).

14) E. Schmelzer and P. C. Heinrich, J. Biol. Chem., 255, 7503 (1980).

15) M. E. Mirault, M. Goldschmidt-Clermont, A. P. Arrigo and A. Tissieres, "Cold Spring Harbor Symp. Quant. Biol.," Vol. 42, Cold Spring Harbor Laboratory, New York, 1978, pp. 819 827.

16) J. H. Elder, R. A. Pickett, J. Hampton and R. A. Lerner, J. Biol. Chem., 252, 6510 (1977).

17) G. Blobel and B. Dobberstein, J. Cell Biol., 67, 835 (1975).

18) N. H. Chua and G. W. Schmidt, J. Cell Biol., 81, 461 (1979).

19) B. Burr, F. A. Burr, I. Rubenstein and M. N. Simon, Proc. Natl. Acad. Sci. U.S.A., 75, 696 (1978).

20) N. Ereken-Tumer, J. D. Richter and N. C. Nielsen, $J$. Biol. Chem., 257, 4016 (1982).

21) K. A. Barton, J. F. Thompson, J. T. Madison, R. Rosenthal, N. P. Jarvis and R. N. Beachy, J. Biol. Chem., 257, 6089 (1982).

22) H. Riezman, E. M. Weir, C. J. Leaver, D. E. Titus and W. M. Becker, Plant Physiol., 65, 40 (1980).

23) R. A. Walk and B. Hock, Biochem. Biophys. Res. Commun., 81, 636 (1978).

24) J. G. Huisman, A. F. M. Moorman and F. N. Verkley, Biochem. Biophys. Res. Commun., 82, 1121 (1978).

25) A. C. Cuming and J. Bennett, Eur. J. Biochem., 118, 71 (1981).

26) B. Dobberstein, G. Blobel and N. H. Chua, Proc. Natl. Acad. Sci. U.S.A., 74, 1.082 (1977).

27) P. E. Highfield and R. J. Ellis, Nature, 271, 420 (1978). 